\title{
河床堆積物の侵食による土砂流出とそれによる 土砂流扇状地の形成に関する研究
}

Fan Formation by the Sediment Runoff Due to River Bed Erosion

$$
\begin{array}{llll}
\text { 京都大学防災研究所 } & \text { 高橋 } & \text { 保 } & \text { Tamotsu Takahashi } \\
\text { 京都大学防災研究所 } & \text { 中川 } & - & \text { Hajime Nakagawa }
\end{array}
$$

We had a localized torrential downpour near the Fukui-Gifu prefectural border in September,1965 (we call this Okuetsu Rainstorm). Especially, Nishitani village in Fukui prefecture (after this disaster, residents in this village moved to another place and now this district is included in Ohno city) suffered crushing damage from this storm. Namely, in Nakajima district which was the main part of the Nishitani village, before the disaster the number of households was 154, but after the disaster, 58 households were swept away and 86 were buried. A distinguishing feature of this disaster was that the bulk of the houses in the main part of the Nakajima district situated on the debris fan which had been formed by the sediment runoff from the Kamata river was buried second floor deep in sediment but not swept away. Judging from the fact-finding survey and data analysis, these houses were buried by the sediment which outflowed and deposited from the Kamata river taking the type of the sediment flow rather than the debris flow.

In this paper, in order to reproduce the burying process of the Nakajima district by the sediment flow, sediment hydrograph of the Kamata river is evaluated by the calculation of the bed level variation at first, then by using this sediment hydrograph as a input boundary condition, simulation of the horizontally twodimensional bed level variation in Nakajima district is carried out, and it is found that the calculated results are comparatively in good agreement with actual phenomena.

Keywords:Okuetsu Rainstorm, sediment hazard, sediment flow, simulation

\section{1 . はじめに}

昭和 40 年 9 月、福井・䀞阜県境付近に集中豪雨（これを奥越豪雨と呼んでいる）が発生し、とくに福井県西 谷村（現在大野市）は壊隇的な災害を被った。すなわち、西谷村の中心をなす中島地区では、被災前の世帯数 154 戸のらち、流失 58 戸、埋没 86 戸を記録し、まさに壊滅状態となった。との災害の特徵は、中島地区の大 部分を構成する鎌田川扇状地上K立地する家屋の大半が、鎌田川から流出した土砂によって所によっては 2 階 まで埋没したものがあるが、在とんど流失には至っていないといらてとである。なお、上記流失戸数 58 戸とあ るのは、その大半は扇状地上に立地していたものではなく、扇状地直下流の真名川の高水敷上に立地していた 家屋が、対岸の斜面崩壊によって真名川に形成された天然ダムの愝上げによる洪水氾濫で流されたものである。 災害調查結果やその後の検討の結果、扇状地上K立地していた中島地区の家屋は、大規模な土石流というより もむしろ、比較的長時間にわたって扇状地背後に展開する鎌田川から流出・堆積した土砂流によって埋没した ものと推察された。

本研究においては，まず、鉡田川からの流出土砂のハイドログラフを、河床堆積物の侵食による河床変動を計 算するととにより評価し、その結果得られる下流端での流砂量を扇状地頂部での流入境界条件として用い、扇 状地ての土砂流の氾濫・堆積による中島地区埋没過程の再現を試みる。

\section{2 . 流域および災害の概要}

昭和 40 年 9 月 10 日K台風 23 号が西日本を横断し、ついで 17 日Kは台風 24 号が中部日本を横断して各地 K被害が生じた。ての昭和 40 年 9 月の災害を特徵付けるものは台風そのものによるものではなく、ていらの台 風の間、9月 13 日頃からほぼ本列島に治って停滞していた前線に、まだ $1000 \mathrm{~km}$ 以上離れた位置にあった台 風 24 号が影響して西日本各地に大雨が生じたととである。

福井県地方は 14 日の日中は全般に一様な雨が降っていたが、夜に入って奥越地方に集中して激しく降り、15 日の 15 時過されなってよらやく降雨域も分散し始め、それが東の方へ移動し始めて集中豪雨は解消に向かった。 本集中豪雨の中心となった福井県西谷村本戸では、14 日 9 時から 15 日 9 時までの日雨量が $844 \mathrm{~mm} 、 13$ 日 9 時

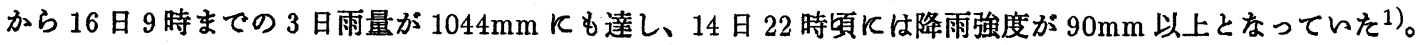


中島地区は図 1 K示すよう 笹生川と雲川 との合流点にあり、地区の中心を鎌谷（鎌田 川）が貫流している。すなわち、中島地区の 主要部分はこの鎌谷が形成した扇状地上飞立 地していたのである。文献2),3),4),5)および著者 の内の一人の当時の聞き取り等によると、災 害の時間経過は以下のようである。

9 月 14 日 19 時頃より特に激しく降り出し を集中豪雨は、21 時頃から、鎌田川からのお びただしい土砂流出をもたらし、夜半から 15 日の 2 時頃にかけて、役場中学校を含む中島 地区の大半を埋没させ、一部の家屋を流失せ しめた。その間、 9 月 14 日 22 時頃には笹生 川を挟んだ対岸にある木落し谷も土石流を発

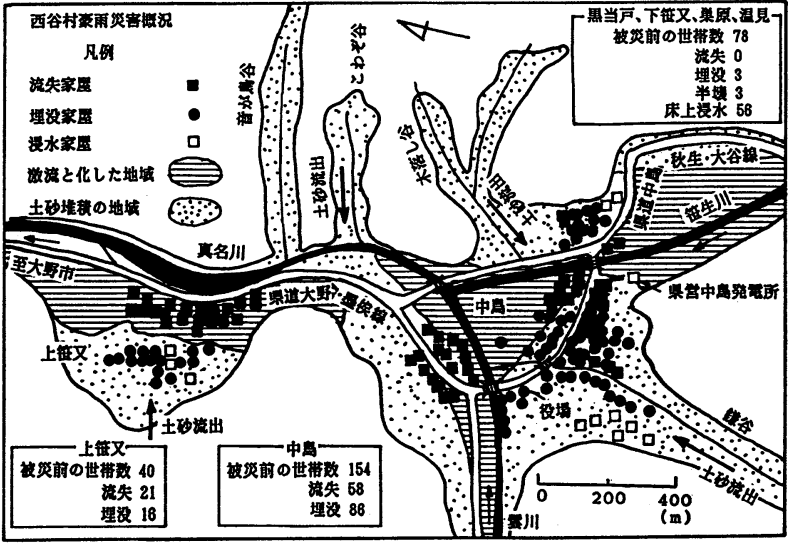

図 1 中島および上笹又の被災状況(文献1)上り) 生し、家屋 3 戸を埋没させた。また、笹生川に架かる県道のコンクリート橋の橋台部分が流失し、笹生川の洪水 が対岸側の中島地区を直撃するよらな形となって扇状地の東側 $1 / 3$ 位に立地する家屋をととどとく流失させた。

15 日午前 8 時 30 分（文献 3) Kよる。文献 2) では 10 時、4)では 11 時頃、1)では 8 時 5 分とある。）コアソ 谷に山崩れが発生し、とれが真名川を堰を止める天然ダムを形成した。とのため、ダム上流部で洪水が上流人 波及し、15 日 9 時頃 ${ }^{3)}$ 中島地区の雲川左岸側の家屋を上流一向かって流失させた。ての天然ダムはやがて決壊 し、それによって生じた大洪水が約 $1 \mathrm{~km}$ 下流の上笹又を典い、地区前の㺫底が土砂で浅くなって川幅が次第に 家屋群の方向に桩大して、15 日の 11 時頃には上笹又の川岸に近い 21 戸が流失した。

上記の経過より明らかなよらに、流失家屋の大半は天然ダムの影響による洪水々橋梁付近の岸决壊・洪水氾 濫によっており、土砂流出によっては、二階まで埋没しているものがあるがほとんど流失に至っていないので ある。すなわち、鎌田川および上笹又の莗山の沢からの土砂流出は大規模な土石流と言らょりも、むしろ、比 較的長時間にわたって流出・堆積した土砂流によるものと推察される。

中島地区では上記のよらな甚大な被害を受けたが、地区住民には死者・行方不明者は一人も生じていないの が不幸中の幸いであった。とれは、14 日の 21 時頃には鎌田川K架かったコンクリートの橋の上を流れが越え、 川は腐敗した泥のような悪臭を放ち濁流となって流れていたてとから、村当局が危険を察知して直ちに地区住 民に避難命令を出し、住民を扇頂部付近の比較的安全な場所にある寺へ避難させたてとによっている2）。

3.鎌田川の洪水ハイドロダラフ

すでK述へたよらK、福井県西谷村中島地区の大半を埋没させた原因はその背後 凡展開する鎌谷（鎌田川）からの土砂流出であった。とてでは、まずその土砂流出 を生ぜしめを洪水ハイドログラフの再現を行う。

鎌田川は図 2 K示すようK、羽毛状をした流域面積約 $3.8 \mathrm{~km}^{2}$ の小河川である。 主流路長は約 $3,400 \mathrm{~m}$ であり、その縦断形状は図 3 のよらで、下流側約 $1 / 3$ が上流 部に比べて急勾配となている。しかしながら本流域の渓床勾配は支渓も含めて土石 流発生勾配 $\left(15^{\circ}\right)$ よりも䌅く、中島地区を埋めた土砂は掃流あるいは掃流状集合 流動として流出したものであると考えられる。実際に災害直後に撮影された空中写 真（撮影：昭和 40 年 10 月 1 日, $1 / 12,500$, 阪急航空）Kおいても、上流部支溪およ び本流にはとくに土石流痕跡は認められず、主として中流以下の主流の侵食による 土砂が流出したととを示唆している。

さて、本流域から土砂流出量を求めるには、まず、洪水流出量を把挃する必要が ある。流出計算法には各種のものがあるが、基礎となる資料がほとんどないので、 こてでは簡単な線形の眝留関数法6)を適用する。すなわち、流域平均眝留高 $s(\mathrm{~mm})$

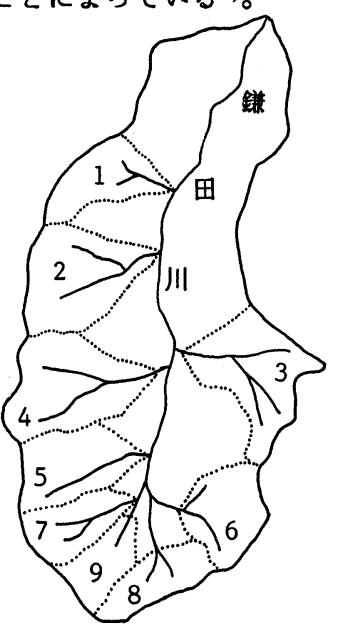

図 2 鎌田川平面図 が比流量 $q(\mathrm{~mm} / \mathrm{hr})$ K一次比例すると仮定し、降雨強度を $r(\mathrm{~mm} / \mathrm{hr})$ として連続式を用らると次式が得られる。

$$
k \frac{d q}{d t}=r-q
$$


ととK、kは比例定数である。とれを階差式に直すと次式 のよらКなる。

$k \frac{q(t+\Delta t)-q(t)}{\Delta t}=\frac{r(t+\Delta t)+r(t)}{2}-\frac{q(t+\Delta t)+q(t)}{2}$

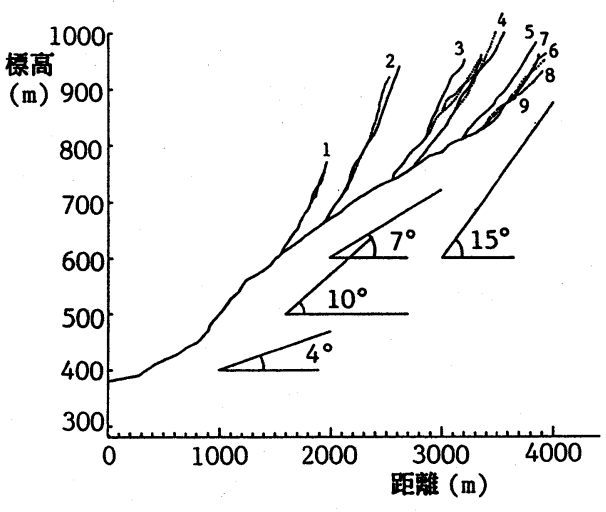

結局、比流量 $q$ は次式となる。

$$
q(t+\Delta t)=C \frac{r(t+\Delta t)+r(t)}{2}+(1-C) q(t)
$$

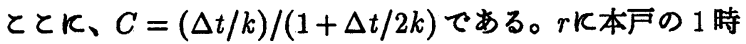
間降雨強度を与え、 $C=0.3$ 、初期流量を 0 として (3) 式 を計算した結果を図 4 K示す。てのようとして求めた最大 流量 $79 \mathrm{~m}^{3} / \mathrm{sec}$ は、合理式

$$
Q_{p}=\frac{1}{3.6} f r A
$$

Кまいて $f=0.8, r=89 \mathrm{~mm} / \mathrm{hr}$ (本戸の最大降雨 強度）, $A=3.8 \mathrm{~km}^{2}$ として求めたピーク流量 $Q_{p}=$ $75 \mathrm{~m}^{3} / \mathrm{sec}$ と性䚾一致している。

図4の流量ハイドログラフは流域出口Kおけるも のであるが、主流以沿って流砂量を求めるためには、 主流の各場所ての流量ハイドログラフが必要となる。 実際には支溪が合流する地点で離散的に流量が変化 するはずであるが、本流域が比較的長方形に近い羽 毛状流城であるととから、主流路延長 $L(=3,400 \mathrm{~m})$ K沿って一様な横流入があるものとみなす。流水が 主流の最上流から流城出口まで到達するのK必要な 時間を無視すれば

$$
Q_{I}+q_{\text {in }} L=Q_{0}
$$

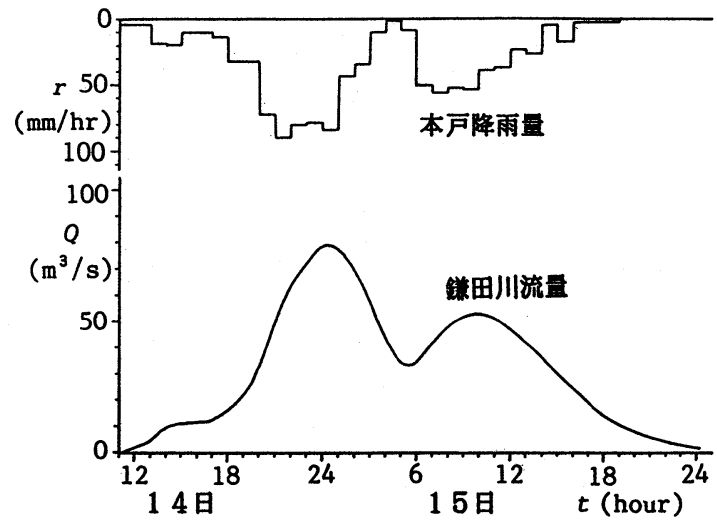

因 4 鎌田川の計算ハイドログラフ

が成立する。ととK、 $Q_{I}$; 主流最上流人流入する流量、 $q_{i n}$; 主流路単位長さ当りの横流入流量、 $Q_{0}$; 流域出口の流 量である。最上流の支溪の流城面積は $0.13 \mathrm{~km}^{2}$ であるのて、 $Q_{I}=(0.13 / 3.8) Q_{0}=0.034 Q_{0}$ として $L=3,400 \mathrm{~m}$ を代入して (5) 式から $q_{\text {in }}$ を求めるてとがでをる。

4 . 鎑田川の土砂ハイドログラフ

流砂量は以下の式を連立して解くととKよって求められる。

水流の運動量式:

$$
\frac{\partial M}{\partial t}+\frac{\partial(u M)}{\partial x}=g h \sin \theta_{x}-g h \cos \theta_{x} \frac{\partial\left(z_{b}+h\right)}{\partial x}-\frac{\tau_{b}}{\rho}
$$

水流の連続式:

$$
\frac{\partial h}{\partial t}+\frac{\partial M}{\partial x}=q_{\text {in }}
$$

抵抗則:

$$
\frac{\tau_{b}}{\rho}=\frac{f}{8} u|u|=\frac{g n^{2} u|u|}{h^{1 / 3}}
$$

流砂量式火は、急勾配の掃流状集合流動をも含んだ領城で成立する次式7)を用いる。

$$
\begin{array}{cc}
\frac{q_{b}}{\sqrt{(\sigma / \rho-1) g d}}=\frac{1+5 \tan \theta}{\cos \theta} \sqrt{\frac{8}{f}} \tau_{*}^{3 / 2}\left(1-\alpha^{2} \frac{\tau_{* c}}{\tau_{*}}\right)\left(1-\alpha \sqrt{\frac{\tau_{* c}}{\tau_{*}}}\right) \\
\text { エネルキー勾配: } \\
I_{e}=\frac{\tau_{b}}{\rho g h}=\frac{n^{2} u|u|}{h^{4 / 3}}
\end{array}
$$


流础の連続式: $\quad \frac{\partial z_{b}}{\partial t}+\frac{1}{C_{*}} \frac{\partial q_{b}}{\partial x}=0$

ととK、 $M=u h, u$; 平均流速, $h$; 水潹, $n$; マニングの 粗度係数, $\theta_{x} ; x$ 軸の傾斜角, $\tau_{b} ;$ 底面摩摖力, $\rho$; 水の密 度, $\sigma ;$ 砂磞の密度, $g$; 重力加速度, $z_{b}$; 堆積厚さ, $f ;$ 糜擦 損失係数, $q_{b} ;$ 単位幅流砂量, $\tau_{*} ;$ 無次元掃流力, $\tau_{* c} ;$ 無 次元限界掅流力 $\left(=0.04 \times 10^{1.72 I_{e}}\right), \alpha$; 係数, $C_{*} ;$ 堆 積層の秒䃏濃度である。ただし、

$$
\begin{aligned}
& \alpha^{2}=\frac{2\left(0.425-\frac{\sigma}{\sigma-\rho} \tan \theta\right)}{1-\frac{\sigma}{\sigma-\rho} \tan \theta} \\
& \tau_{*} \geq 0.2 \text { のとき: } \sqrt{\frac{8}{f}}=A+5.75 \log \left\{\frac{(\sigma / \rho-1) \tau_{*}}{I_{e}\left(1+2 \tau_{*}\right)}\right\} \\
& \tau_{*}<0.2 \text { のとき: } \sqrt{\frac{8}{f}}=A+5.75 \log \left\{\frac{0.2(\sigma / \rho-1)}{1.4 I_{e}}\right\} \\
& I_{e} \geq 0.08 \text { とを: } A=0.04 I_{e}^{-2} \\
& I_{e}<0.08 \text { のを: } A=6.0
\end{aligned}
$$

である。

鎌田川の代表的河幅を求めるためと、断面につ々て $1 / 25,000$ の地形因から横断面形を求め、代表河幅として $20 \mathrm{~m}$ を採用した。代表粒径は不明であるが、とてでは、実地調查時の印象から $d=5 \mathrm{~cm}$ を用いた。(13)および (14) 式を用いると摩搮損失係数が求まり、マニングの粗度係数は与える必要が無いのであるが、(13),(14) 式か ら $f$ を求める手続きはかなり複雑であるため、ととではマニングの粗度係数 $n=0.03$ の一定値を与えて水流长 関する計算をまず行い、その後、流砂量の計算にのみ (13),(14) 式を用いた。とのよらな方法は多少の矛盾を含 んでいるとしなければならないが、とてでは流出土砂量のまよその検討をするのが目的であるのでてのような 便法をとっている。

図 5 はてのようKして求めた鎌田川出口での流出土砂量である。ただし、とれは実質体積を示しており、総 流出土砂量は約 16 万 $\mathrm{m}^{3}$ となっている。流出した土砂が堆積した場合の空隙率を $35 \%\left(C_{*}=0.65\right)$ とすれば、 堆積した土砂の体積は 24.6 万 $\mathrm{m}^{3}$ となり、当時の中島での堆積土量が約 17 万 $\mathrm{m}^{3}$ と言われている ${ }^{8}$ ととからす れば、本川へ流出した分を差し引んても少し過大な見積りかも知れないが、当時の見積りの精度の問題中堆積 土砂の平均粒径がもら少し大きかったてとも考えられる。

図 6 は鎌田川の河床㚆動の計算結果である。実際には下 流部には砧防ダムが存在していたし、上流部の河道の状沉 など詳しい踏查もしていないので、とのような計算結果が どれほど実際の現象を説明しているかよく分からないが、 河床変動の傾向は出ているものと思われる。なお、下流端 では河床高が変化しない条件、すなわち下流端格子K和け る流出流砂量火は直上流の流砂量を与えている。それにし ても河床低下量が約 $10 \mathrm{~m}$ 程度の部分があるのはやや過大 かも知れないが、そのようになった原因としては、先のよ ら火粒径を少し小さ目に見積ったととや、支溪からの流砂 量を無視しているとと等が考えられる。 5 . 中島扇状地の土砂埋没過程

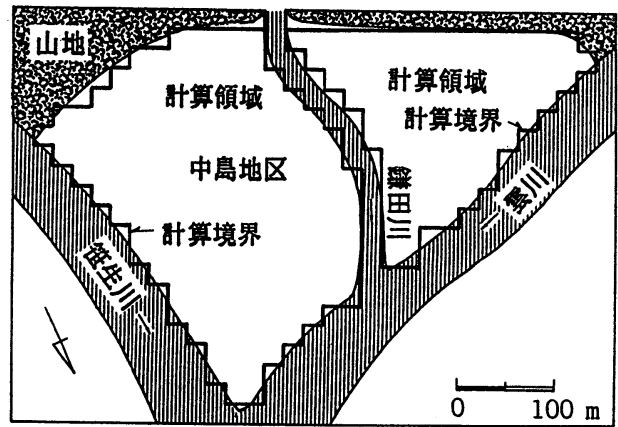

図 7 中島扇状地

さて、図 5 のような土砂流出があったものとして、四 7 のようK簡略化して示した中島扇状地上への氾濫・ 
堆積過程の解析を行ってみる。解析は上記水流および流砂量の式を二次元場のものK変換するてとKよって行 える。用いる基礎方程式系は以下のよらである。

$$
\begin{array}{lc}
\text { 水流の } x \text { 方向運動量式: } & \frac{\partial M}{\partial t}+\frac{\partial(u M)}{\partial x}+\frac{\partial(v M)}{\partial y}=g h \sin \theta_{x}-g h \cos \theta_{x} \frac{\partial\left(z_{b}+h\right)}{\partial x}-\frac{\tau_{b x}}{\rho} \\
\text { 水流のy方向運動量式: } & \frac{\partial N}{\partial t}+\frac{\partial(u N)}{\partial x}+\frac{\partial(v N)}{\partial y}=g h \sin \theta_{y}-g h \cos \theta_{y} \frac{\partial\left(z_{b}+h\right)}{\partial y}-\frac{\tau_{b y}}{\rho} \\
\text { 水流の連続式: } & \frac{\partial h}{\partial t}+\frac{\partial M}{\partial x}+\frac{\partial N}{\partial y}=0 \\
\text { 抵抗則: } & \frac{\tau_{b x}}{\rho}=\frac{g n^{2} u \sqrt{u^{2}+v^{2}}}{h^{1 / 3}}, \frac{\tau_{b y}}{\rho}=\frac{g n^{2} v \sqrt{u^{2}+v^{2}}}{h^{1 / 3}} \\
\text { 流砂の連続式: } & \frac{\partial z_{b}}{\partial t}+\frac{1}{C_{*}}\left(\frac{\partial q_{b x}}{\partial x}+\frac{\partial q_{b y}}{\partial y}\right)=0
\end{array}
$$

流砂量は一次元の (9) 式を用いるが、とれを

$$
q_{b x}=\frac{u}{\sqrt{u^{2}+v^{2}}} q_{b} \quad, \quad q_{b y}=\frac{v}{\sqrt{u^{2}+v^{2}}} q_{b}
$$

のようK流速成分の比で $x$ 成分と $y$ 成分に配分する。流砂量式K含まれる限界掃流力は一次元の場合と同じく、

$$
\tau_{* c}=0.04 \times 10^{1.72 I_{e}}
$$

を用レる。ととK、I $I_{e}$ は流れのエネルギー勾配で、次式で表わされる。

$$
I_{e}=\tan \theta=\frac{n^{2} U|U|}{h^{4 / 3}} \quad, \quad U=\sqrt{u^{2}+v^{2}}
$$

計算に際して、空間差分間隔として $\Delta x=\Delta y=20 \mathrm{~m}$, 時間差分間隔として $\Delta t=0.2 \mathrm{sec}$ とし、鎌田川を格子 サイズに選んでその深さを $1.5 \mathrm{~m}$ とし、扇面は扇頂部から河川合流点へ向けて一方向にだけ $2^{\circ}$ の傾斜を持つ平 面であると仮定している。また、雲川および笹生川と接続する鎌田川および扇状地の下流端はいずれも段落ち 状熊火なっているものとする。

図 8 は氾濫・堆積過程の解析結果である。本計算においては 14 日 20 時には扇面への薄い氾濫が生じており、 目撃記録の 21 時頃よりも少し早めのようであるが、流出土砂量の計算では扇頂部上流に存在していた砂防ダム の効果を考慮していないのでそのようKなったのかも知れない。図には順次氾濫面の拡がりと堆積厚さの增大 の傾向を時間を追って示している。15 日の 5 時には汇濫ははほ扇面全体に達しており、堆積厚さも扇頂付近で は $2 \sim 3 \mathrm{~m}$ K達している。15 日の 23 時の最終状態においては、扇面全体が $1 \sim 4 \mathrm{~m}$ の土砂に覆われており、実 祭の状況とほぼ一致している。

6 . おわりに

土石流扇状地の二次的な侵食による土砂流扇状地の形成につレては、以前、水理実験と数值シミュレーション との比較を行い、本手法である程度現象が説明されるととを示したが $\left.{ }^{9}\right) 、$ 実際の土砂流の氾濫・堆積現象にもと てで示したモデルが適用可能であるととが確認できた。土砂流は土石流同様強大な破壊力を持っており、土砂 災害を軽減するためにもその流動のメカニズムをさらに詳細に明らかにし、それをもとにハードおよびソフト 対策を講じるととが重要である。今後、土砂の粒度分布を考虑した解析についても検討を加えていく予定である。

\section{〈参考文献〉}

1) 全国防災協会:かが国の災害誌（続）,1976,pp.248-254.

2) 科学技術庁資源調查会:九頭竜川の治山治水調查に関する報告, $1966,324 \mathrm{p}$.

3) 横田忠夫:西谷村水害被災者調查報告,1965,p.17.

4) 科学技術庁資源開発調查会:九頭竜川流域の水害地形々土地利用, $1968,214 \mathrm{p}$.

5) 芦田和男・土屋義人・村本嘉雄・大同淳之:土砂流出K伴ら洪水苂害飞関する研究 一九頭竜川の洪水災害一， 
文部省科学研究費特定研究成果報告畫（昭和 40 年 9 月の豪雨および 24 号台風による風水害の調查とその防災 研究, 研究代表者:松沢 勲) ,1966,pp.68-78.

6) 京都大学防災研究所富山地区災害調查グループ:富山地区災害調查, 昭和 44 年 8 月水災害の総合調查研桀報告 書,1970,pp.40-85.

7)Takahashi,T.:High Velocity Flow in Steep Erodible Channels, Proc. of Session A, XXII Cong., IAHR, Topics in Fluvial Hydraulics, 1987, pp.42-53.

8) 福井県:三大風水害の記録,1966,pp.1-280.

9) 高橋 保・中川一・佐藤広章 : 土石流および土破流扇状地の形成に関する研究, 水理講演会論文集, 第 32 回,1988,pp.497-502.
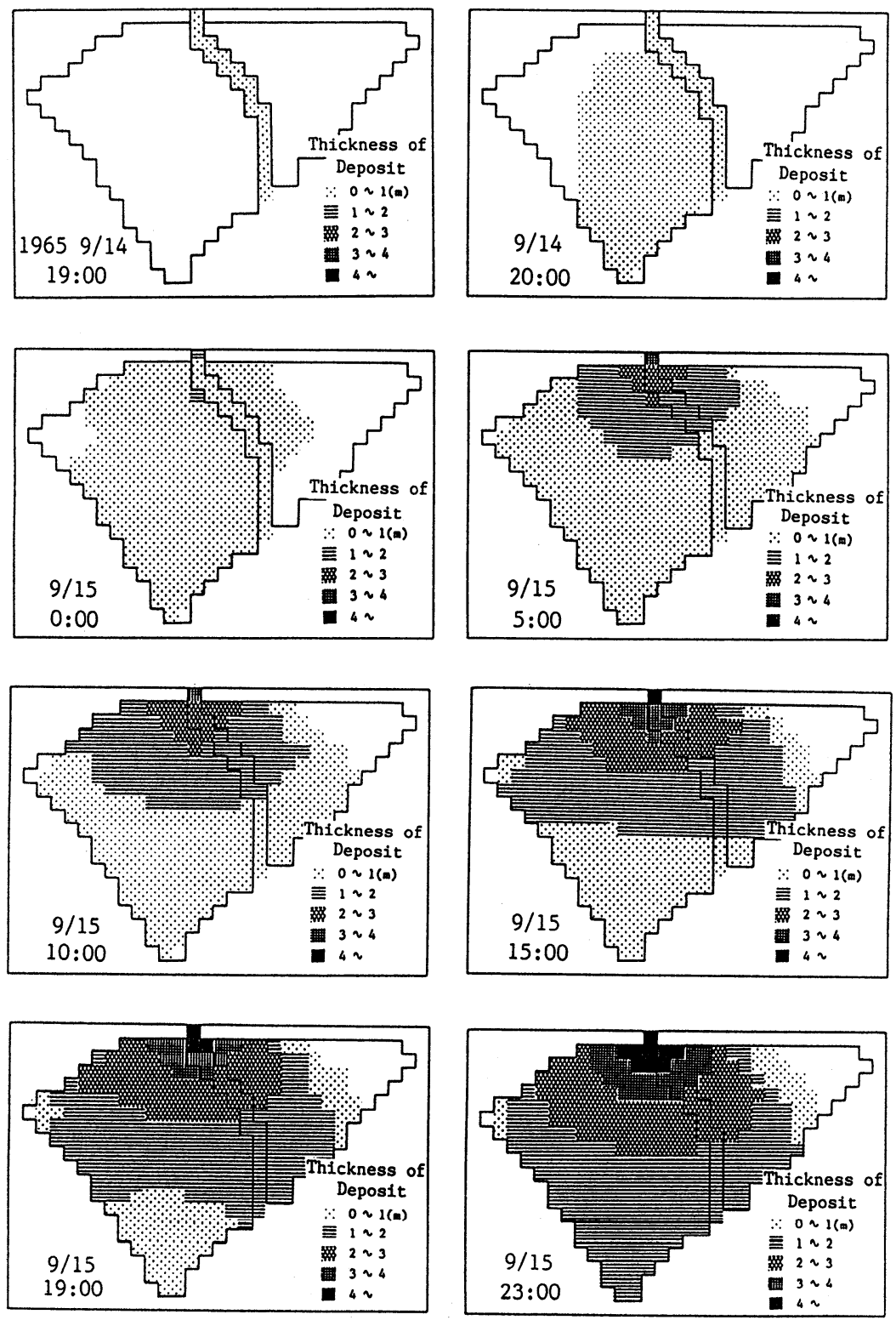

図 8 中島扇状地の埋没ブロセスに関する計算結果 